\title{
The concept of a European public sphere within European public discourse
}

\section{Sanja Ivic}

Institute for European Studies, Belgrade, Serbia

sanja_ivic1@yahoo.com

DOI: http://dx.doi.org/10.5324/eip.v11i2.1959

(cc) BY This is an open access article distributed under the terms of the Creative Commons Attribution 4.0 International License, which permits unrestricted use, distribution, and reproduction in any medium, provided the original author and source are credited.

This inquiry analyses the concept of a 'European public sphere' within the European public discourse. In particular, it explores the European Communication Strategy for creating an active European citizenship and European public sphere. The European Commission's Plan D for Democracy, Dialogue and Debate failed, because it employed homogeneous and static concepts of public sphere and European values. In this way it reduced deliberation to a mere debate. The European Year of Citizens was not sufficiently successful for the same reason. It involved citizens who debated about EU rights, but it did not produce deliberation. The purpose of this inquiry is to show the dialectical relation between the ideas of European values, European identity and European public sphere. This paper emphasizes the performative nature of a European public sphere, European identity and European values. These concepts may be perceived as grand narratives, which aim to generate universal truths.

Keywords: European, public, sphere, discourse, identity, values.

\section{Introduction}

This inquiry analyses the concept of a 'European public sphere' within the European public discourse. In particular, it explores the European Communication Strategy for creating an active European citizen ship and European public sphere. In the last two decades, the question of the European public sphere was often understood within the context of discussions of the European 'democratic deficit'. A deeper look at how European political institutions create and affect the European public sphere has not yet been sufficiently explored. This paper broadens this discussion and analyses various deliberative democratic attempts to construct the European public sphere. In particular, the European Commission's Plan D for Democracy, Dialogue and Debate (Plan D) and the European Commission's proposal for the "European Year of Citizens" will be analysed.

This article advocates deliberation and deliberative democracy as effective tools to create a more inclusive European citizenship and European public sphere. Deliberative democracy also solves the problem of the Union's democratic legitimacy. The European Commission made several deliberative democratic attempts to create an active European citizenship and European public sphere. Former European Commission President José Manuel Barroso states: 'I would like to 
see the development of a European public space, where European issues are discussed and debated from a European standpoint. We cannot continue trying to solve European problems just with national solutions' (Barroso 2012).

Both the European Commission's Plan D for Democracy, Dialogue and Debate and the European Year of Citizens advocate deliberative democracy as a necessary part of active citizenship. However, these attempts were not successful since they led to mere debate, not deliberation. Another problem to be taken into account in this paper is the static and homogeneous understanding of the public sphere within the European legal documents.

The purpose of this inquiry is to show the dialectical relationship between ideas of European values, European identity and the European public sphere. Concepts of 'European values', 'European identity' and the 'European public sphere' should not be understood as homogeneous and static. They should be perceived as dynamic and polymorphous, because they are constantly reinterpreted and adjusted. This paper aims to show that successful deliberation at the European level requires that 'European values' and the 'European public sphere' be understood as heterogeneous, contingent and shifting concepts.

The method employed in this paper is multidisciplinary. It is based on a discursive approach, since discourse is central to understanding both European democracy and the European public sphere. The method of political discourse analysis is fragmented and heterogeneous due to the multidisciplinary nature of the field, which includes various approaches. Political discourse analysis involves various conceptual and methodological approaches.

This inquiry also relies on Derrida's deconstructive approach, which aims at rethinking traditional concepts, such as 'public sphere', 'identity', 'European values', and 'democracy'. Postmodern and

'poststructuralist approaches emphasize the performative and enacting quality of discourses, while focusing on power relations inherent in discursive practices. Discourse is often regarded as the key entry point to access the social world (...) Poststructuralism establishes a relationship of co-constitutionalism between the social world and the subject, the social structure and the agents' (Carta \& Wodak 2015: 6).

However, poststructuralist and postmodern approaches include various points of views represented by different authors. Derrida's deconstructive approach questions and redefines some of the main concepts of European legal and political discourse. The main concepts in European law and politics are constructed rather than fixed. That means that they can constantly be reread and transformed. Applying Derrida's deconstructive approach to the European legal and political discourse includes two tasks. The first one is to deconstruct the definitions and standards that represent the foundation of dominant European discourse. This task questions the 'objectivity' and 'rationality' of the main concepts employed in legal and political discourse. The second task is to transform the main definitions and standards - that is, to reconstruct them. It rebuilds the basic concepts of European legal and political discourse in such a way that they do not reinforce or support dominance produced by various binary oppositions.

Derrida (1992) aims to deconstruct the idea of a Europe based on the ideals of the Enlightenment and contemplates a 'post-Enlightenment' Europe that is capable of 'self-critique' and constant reinterpretation of its values and goals. This 'postEnlightenment' Europe overcomes Eurocentrism; within this idea of Europe, 
Derrida deconstructs the notions of European values and identity as defined by static definitions stemming from the idea of 'European heritage'. Instead, he suggests that these values and identity be perceived as contingent and polyphonic as tasks. European identity and values are dynamic and fluid categories that cannot be adequately tackled by traditional methods of legal and political studies, which do not take into account the flexible and shifting nature of identities, values and political discourses. For this reason, Derrida's perspective offers an adequate approach to the question of European democracy and European identity and values, since it is based on the constant reinterpretation of concepts and overcomes and rethinks binary oppositions, such as we/they, self/other, European/non-European, or citizen/refugee.

Derrida's deconstructive approach, when applied to questions of contemporary Europe, aims to overcome the tension between Europe and its 'other'. This is where, for Derrida, a link between (European) heritage and its promise lies. 'Derrida reads the discourses of Europe, highlights their aporetic tension and temporal disjunction, demonstrating the points of instability and contradictions without achieving reconciliation, but making possible the re-affirmation of Europe' (Caraus 2014).

According to Derrida (1974), one cannot make a sharp distinction between 'self' and 'other', as 'self' always includes the phantom of the 'other' - their relationship is dialectical. Political self-understanding in the EU is created by public discourse (Medrano 2009: 81-82). The discursive and deconstructive approach is an effective way to tackle the struggles for recognition of various social groups. These issues address the question of whether equality in the practices and institutions of the European Union is compatible with the preservation of various identities, values and interests. Struggles for recognition can be effective only if essentialist and quasiessentialist conceptions of identity are reformulated towards contingent notions of identity. Identities are open texts and they include plurality of interpretive horizons in which we can understand both ourselves and the 'other'. The sharp distinction between 'self' and 'other' has to be avoided in political and legal discourse, since these categories are interrelated. Reasoning based on the sharp distinction between the 'self' and 'other' is imperialistic.

The postmodern condition implies pluralism and ambivalence and requires rethinking modernist practice. Derrida reconstructs the concepts of citizenship, identity, values and the notion of public sphere, arguing that these concepts cannot rest on the political heritage of the Enlightenment, which denies particularity and difference. The public sphere should not be perceived as a unitary concept, and it should be considered as heterogeneous.

Consequently, it is even rather insolent to use the term 'public' in relation to politics, since the sphere of common deliberation has now been enlarged to include a wide range of groups and individuals that were previously simply ignored. Fragmentation and eclecticism have turned the political category of state-centered citizenship into a chaotic hotchpotch of values and accounts of civic life. This may not have made the notion of citizenship trivial, but it is certainly making it more problematic (Van Ham 2001: 163). 


\section{The European Commission's Plan D for Democracy, Dialogue and Debate}

The concept of a 'European public sphere' should be perceived as heterogeneous. Thus the Habermasian idea of 'public sphere' presented in his Structural Transformations of the Public Sphere (1989) is not adequate for understanding the European public sphere, since it is homogeneous. It is designed for research in the framework of the nation-state. Therefore, it cannot be applied to a multilayered and supranational political community such as the European Union (EU). Habermas does not acknowledge the multiplicity of (conflicting or overlapping) public spheres (Kellner, 2000). Moreover, the rise of the Internet creates new public spaces and broadens the horizon of dialogue and debate. In this way, new public spheres are produced.

Since the beginning of the 1990s, research on the European public sphere has been on the rise. However, the question of a European public sphere is mostly discussed in the context of the European 'democratic deficit'. ${ }^{1}$ The existence of the democratic deficit in the Union was officially recognized by the European Commission in 2005. A period of reflection was undertaken by the European Commission in order to overcome the crisis in the EU following a negative referendum in the Netherlands and France in 2005. Since 2005 the European Commission has organized a number of initiatives and projects ${ }^{2}$ in order to generate transnational deliberation by European citizens. ${ }^{3}$ The European Commission has mostly focused on the question of inclusion of civil societies and organized groups of citizens.

The Commission was also seeking to redefine the concepts of European values, citizenship, European public space, democracy, European identity, and so forth. Former European Commission Vice-President Margot Wallström presented Plan D for Democracy, Dialogue and Debate in 2005. This plan was based on the idea on engaging Member States with citizens in a debate on Europe and its future. It strove to encourage an active citizenship and European public sphere. This plan was a reaction to the rejection of the European Constitution and aspired to restore public confidence in the European project.

The main purpose of Plan D for Democracy, Dialogue and Debate was to help Member States organize national debates on the future of Europe. Plan D aimed at enabling a broad debate in Member States 'involving citizens, civil society, social partners, national parliaments and political parties' (European Commission 2005). Former Commission Vice-President Margot Wallström believed that these discussions would lead to the creation of a European public sphere.

In recent studies, it is often argued that deliberative democracy can solve the problem of democratic deficit in the EU. Deliberative democracy promotes diversity and pluralism. It is a path towards active and more inclusive citizenship, which is based on participation, inclusion and equal moral worth (Lister 2007). Applied to the European Union, the starting point for deliberative democracy 'could be to look at the notion of the public sphere, the role of parliamentary discourse, and negotiations in the committee system' (Eriksen 1999).

Within the framework of Plan D, thirteen initiatives were presented which endeavoured to stimulate national debates. This plan proposes to include European citizens in the decision-making process in the EU. It emphasizes the significance of the public sphere, civil society and well-informed citizens (European Commission, 2005). Proponents argue that this plan represents a shift from the EU as a project of 
the elite to the EU as a European citizens' project, with the result that the European Commission did not try to rescue the Constitution for Europe. The Commission created Plan $D$ to promote active citizenship. The Action Plan to improve communicating Europe and the White Paper on communication strategy complemented Plan D for Democracy, Dialogue and Debate. These documents had a role to develop and strengthen a European public sphere, 'where citizens are given the information and the tools to actively participate in the decision-making process and gain ownership of the European project' (European Commission 2005).

Plan D was introduced as a 'listening exercise', to enable the European Union to take into account the concerns of its citizens. Plan D for Democracy Dialogue and Debate states:

There is no standard model for the organisation of debates in the Member States. In some, there are permanent structures, forums or platforms which seek to hold regular debates on European issues. In others, there is less of an organised system for dialogue and debate. Models such as the National Forum in Ireland or the Platform for Europe in Spain may offer inspiration to Member States (European Commission 2005).

These dialogues are mostly organized and promoted by national, regional and local parliaments.

According to the main characteristics of Plan D for Democracy, Dialogue and Debate, it seems that it represents a path towards deliberative democracy in the EU. The Commission stated that this plan is based on three principles: 'inclusion (all citizens should have equal access to information on the EU); diversity (all actors should have a voice) and participation (all voices should be heard)' (European Commission 2005). These three principles represent basic traits of deliberative democracy. A number of initiatives represented within the framework of Plan D point to its deliberative character.

However, Plan D did not fulfil its basic purpose. European citizens are still excluded from the decision-making process in the EU. The Treaty of Lisbon was ratified without the open and public debate proposed by Plan D. Former European Commission Vice-President Margot Wallström emphasized that the core idea of Plan D was to transform the EU in accordance with the expectations and concerns of its citizens. Excluding European citizens from the creation of the draft Treaty of Lisbon was contradictory to the conception of citizens as actors of political changes. Consequently, Plan D merely reinforced debate rather than producing deliberation. Debate cannot be equated with deliberation. Debate and dialogue do not always lead to deliberation, which is a broader term. Definitions of deliberation differ, but they all emphasize its power to transform preferences that an agent previously held. On the other hand, the term 'debate' can be applied to an argumentative exchange governed by rules. The debate does not necessarily lead to transformation of preferences. As a result, from the normative point of view, Plan D did not lead to deliberation.

Deliberation is based on the idea that what is common has to be decided in public and not prior to it (Cohen 1991: 29). The result of different processes of consultation and open dialogue proposed by Plan D is nothing more than an open letter that contains a list of 27 recommendations. This letter was presented to the European leaders in December of $2007 .{ }^{4}$ It did not make a substantive change to European citizenship and the decision-making process in the EU, as emphasized in Plan D (European Commission 2007). 
Fishkin argues that the EU lacks a deliberative structure: 'There is yet no deliberative infrastructure for the EU or, at best, it is tentative, frail and suboptional' (Boucher, 2009). Plan D states that the primary responsibility for responding to the call for open dialogue about common European issues rests with Member States. According to Bruell, this point of view is utopian: 'Why should national governments be interested in promoting balanced arguments and quasiobjective information on EU policies, if they are so successful in using them in their blame-games? This request entirely ignores political strategies and struggle upon power positions' (Bruell 2007). Another problem is represented by the concept of 'public sphere' as employed within the framework of Plan D. Plan D states that every public sphere has its unique local, regional and national traits. ${ }^{5}$ However, 'actors within the public sphere are not restricted to territorial division. This means that the public sphere is not a materialized arena restricted to the national, regional and local level' (Bruell 2007). This perspective is contradictory to the idea of open dialogue that transcends borders and includes all European citizens as free and equal. The public spheres cannot be perceived as monolithic bodies, and different spheres and struggles (such as ethnic, class, religious and so forth) have to be recognized within the framework of different public spheres (Bruell 2007). Public spheres are heterogeneous and polyphonic categories.

The European Commission establishes a very limited concept of the public sphere, which is perceived 'as an information-providing instrument' (Bruell 2007). Plan D does not provide the opportunity to realize heterogeneous and contradictory projects, which is the basic characteristic of a democratic public sphere. Consequently, the public sphere can be 'misused as a propagandistic organ' (Bruell 2007).

\section{Discursive production of 'European public sphere', 'European identity' and 'European values'}

The idea of the European public sphere is often connected to the question of European identity (Calhoun 2002; Bruell 2007; Risse \& Grabowsky 2008; Bee 2008). It is often argued that the lack of a strong European identity means the absence of a European public sphere (Risse \& Grabowsky 2008).

The emergence of a European public sphere depends upon constructing a common identity and sense of belonging. It entails dialogue over issues that concern 'Europeans'. On the other hand, 'actively engaging in a discourse on issues of common concerns actually leads to a collective identification process and creates a community of communication rather than presupposing it' (Risse \& Grabowsky 2008: 7). In this way, concepts of a European public sphere and a common European identity are interconnected.

A European public sphere, European values and European identity are constructed through political discourse and social practices. Concepts of 'European values', 'European identity' and 'European public sphere' should not be treated as givens. They should also not be understood as homogeneous and static. They are dynamic and polymorphous, because they are constantly change and require reinterpreting.

For this reason, research on the European public sphere, EU citizenship, identity and values should avoid searching for simple policy solutions or focusing methodological approaches only on monolithic perspectives. It should go beyond 
the traditional understanding of citizenship, identity, law and borders as static, fixed and permanent. Therefore, research should include close textual interpretation and the hermeneutical analysis of legal sources.

The European Commission developed its own ideas of European values and European identity. Both 'European values' and 'European identity' are narrative constructs. 'The EU has invented a symbolic reality in order to define a set of rules and traditions aimed at integrating the European peoples' (Bee 2008: 434). Since 1990, European values have been constructed as the European interpretation of universalist values of human rights, democracy and rule of law. According Viviane Reding, a former European Commissioner for Justice, Fundamental Rights and Citizenship:

Owing to our history, we in Europe often have a different sense of values and fundamental rights than in the USA, as evidenced above all by our reflection of the death penalty and the importance attached to data protection in the EU Charter of Fundamental Rights. We in Europe also have a different view of the relationship between the market and the state (Reding 2012).

The European identity ${ }^{6}$ was established by the Declaration on European Identity (1973). ${ }^{7}$ Defining European identity within the framework of this document involves taking into account the dynamic nature of European unification and reviewing the common heritage. A collective identity in the EU can subsequently stimulate the formation of a European public sphere. Eriksen emphasizes that the public sphere is not missing in the EU as there are new social movements, identity politics and European audio-visual spaces such as newspapers, television and so forth (Eriksen 1999).

However, the public sphere should not be considered a homogeneous category defined by borders. There are different public spheres in the EU: local, regional, national, European, general and so forth. They are not all monolithic and they all contain different groups. Eriksen emphasizes that pluralism of public spheres leads to fragmentation, but that, on the other hand, more public spheres lead to more debate, and consequently to more democracy (Eriksen 1999).

The European Commission proclaimed 2013 as the 'European Year of Citizens' aimed at encouraging public debate and informing citizens about their rights. It strove to close the gap between European citizens and European institutions and to strengthen the European public sphere and active EU citizenship (Van de Putte 2014). One of the objectives of the European Year of Citizens was to invite citizens to debate on various European issues: citizens' EU rights, the economic crisis and the future of Europe. The European Year of Citizens sought to encourage 'the participation of citizens in the construction of the European Union of tomorrow' (European Commission 2014).

The European Year of Citizens was complemented by a number of Citizens' Dialogues. EU citizens had opportunity to debate with relevant EU politicians on various European issues. These Citizens' Dialogues did not lead to deliberation, but only to mere debate (Van de Putte 2014). The same can be argued regarding the European Year of Citizens, which involved citizens who debated about their expectations for the future of the EU and about EU rights. A tagline 'It's about Europe. It's about you. Join the debate' remained unclear as the nature of the debate was not precise (European Commission 2014). This tagline did not raise awareness 
of EU rights despite being one of the main focuses of the European Year of Citizens (European Commission 2014).

The speeches by the former President of the European Commission José Manuel Barroso on the State of the Union (2012) and by Viviane Reding on the United States of Europe (2012) are significant for understanding the main ideas of the European Year of Citizens 2013. ${ }^{8}$ Both speeches focus on the ideas of European public space and European values (Van de Putte 2014). Viviane Reding advocates the idea of a 'United States of Europe', emphasizing 'the specific context of European history, our values and the unique diversity' (Reding 2012). Reding often employs terms such as 'our goal in Europe', 'we in Europe', and 'our values'. She uses these terms as constatives, although they are in fact performatives.

Representatives of postmodern theory perceive identity as performative, not constative. Judith Butler (1990), Jacques Derrida (1986) and a number of poststructuralist, postmodern and queer theorists argue that identity is performative. Consequently, identity does not pre-exist the discursive field. This means that 'we come to understand who we are through the re-iteration or performance of identity. In this sense, identity is not about fixed attributes possessed by individuals, but is instead constructed in a variety of ways at a variety of levels' (Morgan 2000: 217).

Postmodern hermeneutics of the subject rejects the idea of contemplative knower and objective knowing. Interpretative situations are oriented towards the text. The subject who interprets the text is perceived as decentred, polyphonic, and unstable. Postmodernism celebrates heterogeneity. Both subjects (social groups) and texts are perceived as heterogeneous. The heterogeneous character of social groups is explained by various narratives and experiences of the group's representatives, which cannot be universalized and united into a single metanarrative. On the other hand, the heterogeneous character of the text is explained by intertextuality, whereby the meaning of the text is always shaped by another text.

Performative discourse dictates fixed standards and criteria and does not leave room for difference. Poststructuralist and postmodernist authors tend to stress various binary oppositions which represent metanarrative presuppositions, on which various power relations are created. Poststructuralist and postmodern authors argue about the performative character of identity, which is always constructed by discursive practices. Thus no 'objective' European values and European identity exist. Legal texts and political discourses are instruments of power relations and constructions of identities and values. 'While recognising the performative and enacting quality of discourses, post-structuralist scholars place emphasis on the concept of power' (Carta \& Morin 2014: 8).

According to Derrida, the politics of (fixed) identity, which privileges unity, represents dangerous ethics and politics (Caputo 1997: 13). Derrida rejects as illusion the idea of identity based on totality and unity. He argues that linguistic, cultural and national identities are different from themselves. This means that identity should not be perceived as a homogeneous category. Derrida emphasizes: 'Once you take into account this inner and other difference, then you pay attention to the other and you understand that fighting for your own identity is not exclusive of another identity, it is open to another identity' (Caputo 1997: 13).

In his article 'Declarations of Independence', Derrida performs a textual analysis of the American Declaration of Independence (1776). Derrida asks, 'Who signs... the declarative act which founds a certain institution'? (Derrida 1986: 8). The pronoun 'we' is often used in the Declaration to speak 'in the name of people'. 
But these people do not exist. They do not exist as an entity, it does not exist, before this declaration, not as such. If it gives birth to itself, as free and independent subject, as possible signer, this can hold only in the act of signature. The signature invents the signer (Derrida 1986: 10).

Derrida argues that 'to declare' is a performative (not a constative), which means that the Declaration of Independence of the United States of America 'genuinely constitutes the people of the United States as an independent people authorized to sign each document' (Owensby 1994: 193).

Derrida argues that, on the other hand, the Declaration cannot be authorised without a previously existing independent people. He states that the main paradox is that 'signatures create the people who authorize the signing of the document' (Owensby 1994: 193). Derrida shows the performative nature of the Declaration. He argues that the Declaration creates the people, so it cannot be argued that the Declaration is created by the people (De Ville 2008: 88). Derrida argues that Jefferson can be considered a representative of the people in drafting the Declaration of Independence. However, these people did not exist at the time of drafting the Declaration. 'It is only through the signing of the Declaration that the people come into effect and that the representatives obtain their legitimacy' (De Ville 2008: 97). Derrida makes a distinction between constative and performative. ${ }^{9}$ He argues that 'people' as an entity cannot exist before the act of signature of the Declaration. Derrida argues that the Declaration is presented as a constative, while it can only be considered to be a performative. Subsequently, it does not have any fundamental origin.

Invention of the 'people' can be ascribed both to the American Declaration of Independence and to the European Commission's efforts to develop the public sphere in Europe. Both Reding and Barroso construct the European 'we' from the discourse on 'European values'. However, European values cannot exist without a previously existing European people. Thus one can argue about the performative nature of 'Europeanness' and 'European people' (Van de Putte 2014). 'Europeanisation (...) is a performative intersubjective system by which Europeans define both the European order, and themselves, based on a shared conception of a European political community' (Bélanger 2014: 30).

The performative nature of Europeanisation can be concluded from the European Commissions statement: 'We must build up a European public space and public opinion, so that European citizenship can be fulfilled and completed' (European Commission 2013: 3). Here the pronoun "we" is used in the name of "European people". This is another example of how the 'signature creates the signer'.

The performative construction of European subjects includes the binary opposition we/they. These performative references divide 'European' from 'nonEuropean'. According to Article 49 of the Treaty of the European Union, the EU is open to all European countries. However, the term "European" remains vague and leaves a lot of room for exclusion based on inside/outside dichotomy. The term 'European country' defined by the Treaty of the European Union is mostly understood as a political community, which shares 'European values'. Thus, 'European country' is not defined predominantly geographically. Europe as a continent is divided into 'Europe' and 'non-Europe'. Countries that geographically belong to Europe are not considered 'European' in an economic and political sense. Thus these countries have to be transformed into European ones, regardless of their geographical position and of belonging to Europe as a continent. They have to share 
'European values'. Nevertheless, the notion of 'European' remains vague, since there are different conceptions of 'European values'. From this point of view, one can also argue about symbolic geography and European mental maps of keeping in and keeping out. This symbolic geography stems from the performative nature of European identity and values.

According to Van de Putte, the use of terms such as 'we Europeans', 'our values', or 'us' can often be identified in the phase of creating 'ideology prior to policy making' (Van de Putte 2014: 58). In the policymaking phase, these terms often turn into 'you' and 'your'. This can be identified both in the slogan of the European Year of Citizens ('It's about Europe. It's about you. Join the debate') and in the title of the EU Citizenship Report 2013 ('EU Citizens: Your Rights, Your Future') (Van de Putte 2014: 58). This phrasing creates a sharp distinction between EU citizens ('the you') and 'European institutions' ('us'), which is contrary to the European Commission's efforts to bring European institutions closer to citizens.

\section{Metaphysical origin of Europeanness: Creating narratives for Europe}

Former President of the European Commission José Barroso invited artists and academics to create 'a new narrative for Europe' ${ }^{10}$ (Barroso 2013). These constructed discourses on Europe are, in fact, 'grand narratives', which aim to convince people of certain truths.

The concept of a 'grand narrative' (or metanarrative) was introduced by Jean François Lyotard (1984). 'Grand narrative' is a term often used by postmodern authors, and is thought to be a comprehensive explanation of historical, social, political, scientific or any other kind of knowledge or experience. 'Grand narrative' is a totalizing explanation of events and concepts, which unifies them in to a whole. Postmodern authors use this concept in order to point out unifications that justify various power structures. From the postmodern perspective, science, religion and different political theories can all be perceived as grand narratives. Lyotard describes the 'postmodern condition' as scepticism towards all kinds of totalizing and unifying narratives that point to an 'absolute truth'.

Grand narratives tend to ignore heterogeneity and to unify human experience. Lyotard's vision of politics is based on different 'language games' ${ }^{11}$, and it implies an idea of pluralist truth. Language games construct different truths, as embedded in different contexts. Postmodernists advocate a pluralism of truths, discontinuity and fragmentation. They transcend grand narratives by focusing on the diversity of human experience and specific local contexts. The entire postmodern project aims at liberating various social groups, cultures and identities from the terror of totalizing metanarratives. The fall of grand narratives has led to the emergence of the postmodern fragmentary and shifting notion of identity. 'Postmodern perspectives on the political have tended to adopt non-topographical conceptions which are dynamic and fluid. Rather than focusing on institutions, these perspectives have highlighted discursive, linguistic, psychological and performative moments of political action' (Squires 1998: 121).

Critics of grand narratives do not deny the existence of truth. They emphasize that the truth is always institutionally produced and cannot be separated from its contextual framework. However, some critics of Lyotard's idea of the 'postmodern condition' find it to be inconsistent. and argue that the critique of grand narratives 
can be perceived as a grand narrative itself (Habermas \& Benhabib 1981). Nevertheless, this point of view is based on a misunderstanding of postmodernism and tends to create a unifying metanarrative of shifting, fragmented and polyvalent postmodernist ideas and concepts.

The postmodern approach offers an expanded, alternative idea of the political. As Foucault points out, instead of perceiving power as being based on prohibitions, use of power should be observed as producing a whole range of meanings, identities, bodies, knowledge, beings and actions (Foucault 1984). The meaning is found in the discursive practices that are produced, disputed and transformed in socio-historical actions, rather than in a sui generis scheme of timeless categories. Postmodern theory is shaking homogenous, coherent and monolithic modernist constructions based on reason, and postmodernists question metaphysics based on the logos. Postmodernists believe that homogeneous and fixed identities produce violence and repression, questioning the naïveté and groundlessness of every identity that excludes otherness. As an anti-foundationalist view that includes multiple and shifting identities, postmodernism represents not only the context in which EU citizenship can be studied, but also a source of criticism of essentialist claims of European citizenship, identity and values.

Definitions of European identity, European values and the European public sphere may be perceived as grand narratives. Both European identity and European values are grand narratives that transcend the plurality of Europe (Delanty 2010). 'By improving debate and dialogue between institutions and citizens, the Commission is still trying to develop a new kind of democratic imagined community in which governing takes place in a dialogic environment and in the context of a new demos' (Bee 2008: 437). This democratic imagined community often includes various other grand narratives that point to a metaphysical determination of Europe. One of them is an idea of a 'common destiny'. Former President of the European Commission José Barroso states, 'It is not enough to say that we, Europeans, share a common destiny! A sense of belonging to Europe, to a community of values, culture and interests, is essential to forge that common destiny' (Barroso 2014). The idea of a common destiny of European peoples is also mentioned in the preamble of the Treaty Establishing a Constitution for Europe (2004).

Barroso also argues, 'Europe I believe has a soul. This soul can give us the strength and determination to do what we must do' (Barroso 2012). The Conference 'A Soul for Europe' took place in Berlin on 3 March 2014. The President of the European Commission Jean-Claude Juncker ${ }^{12}$, José Manuel Barroso, Martin Schulz and Guy Verhofstadt debated with writers, movie directors and art festival organizers on how to find 'a soul for Europe'. However, the idea of Europe should be political, and metaphysical assumptions should be avoided. The European Union is dynamic and polyphonic political community and should not be based on 'totalizing metaphysical theories about the nature of things' (Bridges 1994). The concept of the European Union within European political discourse should be revised in order to move towards the postmodern political standpoint which does not base its concepts on metaphysical and moral assumptions, but on a political and constructivist approach which emphasizes heterogeneity and multiple identities. 


\section{Conclusion}

This paper examines the deliberative character of the European Commission's Plan D for Democracy, Dialogue and Debate and the European Year of Citizens. I have argued that deliberation leads towards an active and more inclusive citizenship. However, deliberation is reduced to a mere debate within the framework of Plan D and within the framework of the European Year of Citizens. The European Commission's Plan D for Democracy, Dialogue and Debate failed, because it employed homogeneous and static concepts of the public sphere and European values. In this way it reduced deliberation to a mere debate. The European Year of Citizens was not sufficiently successful for the same reason. It involved citizens who debated about EU rights, but it did not produce deliberation. The tagline 'It's about Europe. It's about you. Join the debate' remained unclear, since the nature of the debate was not precise (European Commission 2014). This tagline did not raise awareness of EU rights, despite being one of the main focuses of the European Year of Citizens. Both Plan D and the European Year of Citizens did not fulfil their aim to close the gap between European citizens and European institutions. This paper emphasized the performative nature of European values and European identity. Performative discourses exclude subjects who do not relate to a fixed definition of European identity and values.

This paper also shows the performative nature of 'European identity', 'European values' and 'Europeanness'. These concepts should not be understood as givens. They are produced by various discourses and may also be perceived as persuasive and convincing grand narratives. Methodologically speaking, one cannot persist with a postmodern model of citizenship when considering some binary oppositions which are difficult to dismiss, namely: European/non-European, self/other, citizen/alien, and so on. Postmodernism applied to European studies primarily refers to the idea of polyphonic and fluid identities, in order to solve the problem of 'internal outsiders' in the EU. Thus, applying postmodern idea of identity to EU citizenship and European identity requires decentralization, as well as recognizing and rejecting essentialist elements. These elements are ones that lead to the homogenization of concepts of 'European values', 'European public sphere' and so on by denying and ignoring the contribution of the other and alterity in the process of creation of these concepts.

It is a fact that European Union citizenship recognizes multilayered and flexible identities within anthropological, philosophical, historical and political studies. However, European public political discourse often ignores or fails to sufficiently emphasize the polyphonic nature of European identity and values.

\section{Notes}

${ }^{1}$ It is often argued that the democratic deficit is due to the lack of a European public sphere, European political parties and representative accountability (Eriksen 1999).

${ }^{2}$ Citizens Conference on New Regional and Urban Sustainability Approaches in Europe, 2005; Meeting of Minds - European Citizens' Deliberation on Brain Science 2005/06; European Citizens' Consultation on the Future of the EU 2006/07, European Citizens' Panel on Rural Areas in Future Europe, 2006/07 and so forth. 
3 The European Commission supported another project of deliberation in 2007, called 'Tomorrow's Europe'. This was a European Deliberative Poll, which included 27 Member States and their citizens.

${ }^{4}$ By this date the Treaty of Lisbon was already drafted.

5 'In seeking to promote a common framework, the Commission fully recognises that each debate has its own local, regional and national characteristics. Different issues will be highlighted and the importance of the European Union will differ according to the country and policy content discussed' (European Commission 2005).

${ }^{6}$ Although the concept of European identity defined in this document can be criticized, it cannot be denied.

${ }^{7}$ At the Copenhagen Summit of 14 and 15 December 1973, the Heads of State of the nine Member States of the enlarged European Community adopted this document.

${ }^{8}$ Both texts were presented on the European Commission's website as references for the main ideas of the European Year of Citizens 2013 (Van de Putte 2014: 43)

${ }^{9}$ Constantive describes what already exists. On the other hand, in a performative speech act the language performs the action it describes. It embraces promises, getting married, giving a gift, making a bet, and so on.

10 'The New Narrative for Europe' Pilot Project was launched at the Center for Fine Arts (BOZAR) in Brussels in 2013. José Manuel Barroso, President of the European Commission, was joined by Commissioners Viviane Reding and Androulla Vassiliou and 100 civil society leaders to initiate this project.

${ }^{11}$ The idea of language games is was introduced by Ludwig Wittgenstein (1953).

12 Jean-Claude Juncker was candidate for this position at that time, while the President of the European Commission in March 2014 was José Manuel Barroso.

\section{References}

Aune, D. E. (2010). Literary criticism. In Aune, D. E. (ed.), The Blackwell companion to the New Testament (pp. 116-139). Cambridge: Blackwell. https://doi.org/10.1002/9781444318937.ch8

Barroso, J. M. (2012). State of the Union 2012 address. European Commission Press Release Database, Strasbourg, 12 September. Retrieved December 18, 2014 from: http://europa.eu/rapid/press-release_SPEECH-12-596_en.htm

Barroso, J. M. (2013). A new narrative for Europe. European Commission Press Release Database, Brussels, 23 April. Retrieved December 19, 2014 from: http://europa.eu/rapid/press-release_SPEECH-13-357_en.htm

Barroso, J. M. (2014). Moving towards a conscience of Europe. European Commission Press Release Database, Natolin, 9 May. Retrieved December 19, 2014 from: http://europa.eu/rapid/press-release_SPEECH-14-368_en.htm

Bee, C. (2008). "Institutionally constructed" European identity: Citizenship and public sphere narrated by the commission. Perspectives on European Politics and Society 9 (4): 431-450. https://doi.org/10.1080/15705850802416861

Bélanger, M. E. (2014). Europeanization as a foundation of the European construction. In Coman, R., Kostera, T. and Tomini, L (eds.), Europeanization and European integration: From incremental to structural 
change, (pp. 29-49). London: Palgrave Macmillan. https://doi.org/10.1057/9781137325501_3

Boucher, S. (2009). If citizens have a voice, who's listening? Lessons from recent citizen consultation experiments for the European Union. CEPS EPIN Working Paper 24: 1-23. Retrieved June 08, 2010 from: https://www.ceps.eu/publications/if-citizens-have-voice-whos-listeninglessons-recent-citizen-consultation-experiments

Bridges, T. (2004). The culture of citizenship: Inventing postmodern civic culture. New York: SUNY Press.

Bruell, C. (2007). Debating Europe - Identity and citizenship in a European democracy. NECE Workshop: The Impacts of National Identities for European Integration as a Focus of Citizenship Education, Tallinn, Estonia, 8-11 September. Retrieved May 10, 2010 from: https://www.bpb.de/system/files/pdf/B1FMMW.pdf

Butler, J. (1990). Performative acts and gender constitution: An essay in phenomenology and feminist theory." In Case, S. E. (ed.), Performing feminisms: Feminist critical theory and theatre, (pp. 270- 282). Baltimore: Johns Hopkins UP.

Calhoun, C. J. (2002). Imagining solidarity: Cosmopolitanism, constitutional patriotism, and the public sphere. Public Sphere 14 (1): 147-171. https://doi.org/10.1215/08992363-14-1-147

Caputo, J. D. (1997). Deconstruction in a nutshell: A conversation with Jacques Derrida. New York: Fordham University Press.

Caraus, T. (2014). Jacques Derrida and the 'Europe of hope'. Open Democracy: Free Thinking for the World, 23 June 2014. Retrieved June 23, 2016 from: https://www.opendemocracy.net/can-europe-make-it/tamara-caraus/jacquesderrida-and-\%e2\%80\%98europe-of-hope\%e2\%80\%99

Carta, C. and Morin, J. F. (2014). Struggling over meanings: Discourses on the EU's international presence. Cooperation and Conflict 49 (3): 295-314. https://doi.org/10.1177/0010836713494995

Cohen, J. (1991). Deliberation and democratic legitimacy. In Hamlin, A. and Pettit, P (eds.), The good polity: Normative analysis of the state (pp. 17-34). Oxford: Basil Blackwell Publishing.

De Ville, J. (2008). Sovereignty without sovereignty: Derrida's declarations of independence. Law and Critique 19: 87-114. https://doi.org/10.1007/s10978008-9024-Z

Delanty, G. (2010). The European heritage from a critical cosmopolitan perspective. LEQS Paper 19: 1-21. Retrieved November 09, 2014 from: http://www.lse.ac.uk/europeanInstitute/LEQS/LEQSPaper19b.pdf

Derrida, J. (1974). Of grammatology, trans. G. Spivak. Baltimore: John Hopkins University Press.

Derrida, J. (1986). Declarations of independence. New Political Science 7(1): 7-15. https://doi.org/10.1080/07393148608429608

Derrida, J. (1992). The other heading: Reflections on today's Europe, trans. Pascale Anne Brault and Michael B. Naas. Bloomington: Indiana University Press.

Eisenstein, Z. R. (1988). The female body and the law. Berkeley: University of California Press. 
Eriksen, E. O. (1999). The question of deliberative supranationalism in the EU. ARENA Working Papers WP 99/4. Retrieved November 15, 2010 from: http://www.arena.uio.no/publications/wp99_4.htm

European Commission (2005). The Commission's contribution to the period of reflection and beyond: Plan $\mathrm{D}$ for democracy, dialogue and debate. COM (2005) 494 final, 13 October, Brussels: Commission of the European Communities. Retrieved June 21, 2009 from: http://ec.europa.eu/ transparency/regdoc/rep/1/2005/EN/1-2005-494-EN-F1-1.Pdf

European Commission. (2007). 2006-2007 Citizen's projects: A concluding conference, December, 7-9, Brussels: European Commission.

European Commission. (2013). Making the most of EU citizenship - Hearing on EU citizenship - 19 February 2013, 19 February 2013, Brussels. Retrieved January 11, 2015 from: http://ec.europa.eu/justice/citizen/document/files/ eu_hearing_report.pdf

European Commission. (2014). Evaluation of the 2013 European year of citizens: Executive summary." Specific Contract No: COM-C2/5/2013, 30 September 2014, Brussels. Retrieved January 28, 2015 from: http://europa.eu/citizens2013/sites/default/files/content/publication/EYC\%20evaluation\%20executive \%20summary\%20FINAL\%20EN.pdf

European Union. (2004). Treaty establishing a constitution for Europe. Official Journal of the European Union, C310, 16 December, Brussels. Retrieved March 20, 2015 from: http://www.refworld.org/docid/41d162834.html

Foucault, M. (1984). The Foucault reader, ed. by Paul Rabinow. New York: Pantheon Books.

Habermas, J. (1989). The structural transformation of the public sphere. Cambridge, MA: MIT Press.

Habermas, J. and Benhabib, S. (1981). Modernity versus postmodernity. New German Critique 22: 3-14. https://doi.org/10.2307/487859

Kellner, D. (2000). Habermas, the public sphere, and democracy: A critical intervention". In Hahn, L. E. (ed.), Perspectives on Habermas (pp. 259-287). Chicago: Open Court.

Lister, R. (2007). Inclusive citizen ship: Realizing the potential. Citizenship Studies 11 (1): 49-61. https://doi.org/10.1080/13621020601099856

Lyotard, J. F. (1984). The postmodern condition: A report on knowledge, trans. Geoff Bennington and Brian Massumi. Manchester: Manchester University Press.

Medrano, J. D. (2009). The public sphere and the European Union's political identity. In Checkel, J. T. and Katzenstein, P. J. (eds.), European identity (pp. 81-107). Cambridge: Cambridge University Press. https://doi.org/10.1017/ CBO9780511806247.005

Morgan, W. (2000). "Queering international human rights law". In Stychin, C. and D. Herman (eds.), Sexuality in the legal arena (pp. 208-225). London: The Athlone Press.

Owensby, J. (1994). Dilthey and the narrative of history. Ithaca and London: Cornell University Press.

Reding, V. (2012). Why we need a United States of Europe now. European Commission Press Release Database, Passau, 8 November. Retrieved February 14, 2015 from: http://europa.eu/rapid/press-release_SPEECH-12-796_en.htm

Risse, T. and Grabowsky, J. K. (2008). Foreign identity formation in the public sphere and in foreign policy. RECON Online Working Paper. Retrieved 
November 02, 2014 from: http://www.reconproject.eu/main.php/ RECON_wp_0804.pdf?fileitem $=50511948$

Squires, J. (1998). In different voices: Deliberative democracy and aestheticist politics." In Good, J. M: and Velody, I. (eds.), Politics of postmodernity (pp.126-146). Cambridge: Cambridge University Press.

Van de Putte, T. (2014). Discourses on democracy. The European year of citizens 2013 and the public sphere”. CEU eTD Collection. Retrieved February 26, 2014 from: http://www.etd.ceu.hu/2014/putte_thomas.pdf

Van Ham, P. (2001). European integration and the postmodern condition: Governance, democracy, identity. London, New York: Routledge. https://doi.org/10.4324/9780203453193

Wittgenstein, L. (1953). Philosophical investigations, trans. G.E.M. Anscombe. Oxford: Basil Blackwell. 